\title{
Teorie OPTIMAL a možnosti jejího využití ve školní tělesné výchově a výuce sportovních her
}

\author{
Possibilities of Using OPTIMAL Theory in School Physical Education \\ and Teaching of Sports Games
}

\author{
Radka Peřinová
}

FTVS UK

\begin{abstract}
Abstrakt
Předkládaná stat'si klade za cíl stručně seznámit čtenáře s hlavními myšlenkami a základními kameny teorie motorického učení OPTIMAL Gabriele Wulf a Rebeccy Lewthwait a poukázat na možnosti jejího využití ve školní tělesné výchově zejména při výuce sportovních her. Autorky kriticky pohliží na "tradični" výuku nových pohybových dovedností a zdůrazňují časté opomijení vnitřní motivace žáků a podporu jejich autonomie. Podle nich je žákům při tradičním vedení výuky vnucováno vnitřní zaměření pozornosti, tedy soustředění na pohyby těla či jeho částí. Uváději, že dưsledkem takového prístupu je učení, které není dostatečně efektivní. Doporučují tedy pedagogům naopak vědomě zvyšovat očekávání žáků, podporovat potřebu autonomie jejich aktivnějším zapojením v učebním procesu a zaměřit pozornost vně směrem $k$ cílům úkolu. Zdá se, že praktické využití teorie OPTIMAL ve školní tělesné výchově je možné. Především podporou autonomie sleduje aktuální trendy. Očekáváme však vysoké nároky kladené na organizaci učebního procesu i na pedagogy samotné. Je tréba teorii ještě $\checkmark$ budoucnu testovat ve školní praxi. Ve sportovních hrách se již řadu let úspěšně užívá didaktické paradigma TGFU (Teaching Games for Understanding). Vzhledem k podobnosti některých principư teorie OPTIMAL a tohoto paradigmatu se jeví, že by i nová teorie motorického učení mohla být zejména při výuce základů herních dovedností ve sportovních hrách úspěšná. I to by však mělo být v budoucnu predmětem testování.
\end{abstract}

Klíčová slova: motorické učení, autonomie, vnější zaměření pozornosti, self-efficacy

\section{Abstract}

The objectives of the prepared article are to give the readers a brief account of the main ideas and foundations stones of a relatively new theory of motor learning, OPTIMAL, formulated by Gabriele Wulf and Rebecca Lewthwait, and also to point out the possibility of its application in school physical education lessons, particularly in teaching sports games. The authors critically assess "traditional" teaching of new locomotor skills stressing the frequent neglect of the internal motivation of pupils and support for their autonomy. According to them, in traditional teaching practice, internal focus of attention is imposed on the pupils, i.e. concentration on the movements of the body or its parts. They claim that the result of such an approach is learning that is not sufficiently effective. On the contrary, they recommend that the teachers should consciously raise the pupils' expectations, support the need for autonomy by their more active involvement in the teaching process and focus their attention externally, towards the goals of the task. It seems that the practical application of the OPTIMAL theory in school physical education lessons is feasible. It is, above, all the support for autonomy that follows the current trends. However, we expect high demands set on the organization of the teaching process and on the teachers themselves. Future testing in the school practice is necessary. The TGFU (Teaching Games for Understanding) didactic paradigm has been successfully used in teaching sports games for a number of years. Due to the similarity of some principles of the OPTIMAL theory and this paradigm, it is apparent that the new theory of motor learning could be successful, too, particularly in teaching the 
fundamentals of game skills in sports games. This assumption, however, should also become a subject of testing in the future.

Keywords: motor learning, autonomy, external focus, self-efficacy

\section{ÚVOD}

Příspěvek byl součástí 13. mezinárodní konference Hry 2018 s tématikou her ve sportovních a tělovýchovných procesech pořádané katedrou tělesné a sportovní výchovy ZČU. Klademe si dva cíle. Představit relativně novou teorii motorického učení a stručně seznámit čtenáře s hlavními myšlenkami i základními kameny, na nichž autorky tuto teorii vybudovaly. Protože tato nová teorie byla zatím uvedena do praxe pouze $v$ některých sportech, je druhým cílem příspěvku analyzovat možnosti jejího využití ve školní tělesné výchově zejména při výuce sportovních her. Naznačit tak možný směr jejího budoucího praktického testování v oblastech našeho zájmu.

Během života se $\mathrm{v}$ mnoha oblastech setkáváme s nutností provádět určité pohyby účinně a dovedně. $Z$ tohoto důvodu je praxe i výzkumy týkající se učení se pohybovým dovednostem stále velmi aktuální. Získávání dovedností je velmi důležité pro jednotlivce, kteří začínají provozovat sport nebo se v něm zdokonalují, učí se hrát na hudební nástroj či řídit nové vozidlo, používají chirurgické nástroje, ovládají robotická zařízení nebo manipulují se zbraněmi v nouzových situacích.

Abychom novou generaci připravili na nároky pracovního, osobního i sportovního života, klademe ve školní tělesné výchově důraz na proces získávání dovedností, a připravujeme tak žáky pro dovedné vykonávání různých pohybových činností. V současnosti existuje řada různých př́stupů ke způsobu, jak získávat nové pohybové dovednosti. Některé jsou využitelné ve školní tělesné výchově, jiné se hodí spíše do sportovního tréninku či k nácviku specifických pohybových dovedností. Teorie, kterou zde představujeme, se mezi tyto prŕstupy zařadila nově. Sportovní hry jsou oblastí, kde je určitá míra zvládnutí specifických dovedností limitou. Ve sportovních hrách se zároveň mnohem více než kde jinde otevírá možnost variability dovedností, a tudíž i prostor pro kreativitu. Je to samožrejmě dáno vysokou proměnlivostí podmínek. V posledních několika desetiletích se řada teoretických studií soustředila na to, jak určité konkrétní podmínky při učení ovlivňují zpracování informací týkající se pohybových úkolů. Výsledky množství takovýchto studií byly východisky při formulaci nové teorie motorického učení OPTIMAL (Optimizing Performance through Intrinsic Motivation and Attention for Learning), kterou počátkem roku 2016 zveřejnily Gabriele Wulf a Rebecca Lewthwaite. Jejich práce není úplnou novinkou. Wulfová sama nebo ve spolupráci s řadou odborníků různého badatelského zaměření publikovala v předchozích letech množství výzkumných studií a představená teorie je jejich logickým vyústěním. V českém prostř̌edí ji osobně představila již koncem roku 2014 na jedné z přednášek uskutečněných v rámci projektu INTERFTEK (Internacionalizace fakulty tělesné kultury) na FTK UP v Olomouci. Druhou přednášku na stejné téma, již po oficiálním zveřejnění, tam měla vloni v dubnu.

\section{OPTIMAL - základní myšlenky}

Wulfová se řadu let zabývá výzkumem pohybového výkonu a učením pohybových dovedností. Pokusíme se zde reprodukovat hlavní myšlenky představované teorie OPTIMAL společně s odkazy na některé z mnoha výzkumů, které její vznik podpořily. Výzkumy, které předcházely formulaci teorie a byly jejími „základními kameny“, byly zaměřené na: 
a) podmínky, které zvyšují očekávání pro budoucí výkon (enhanced expectancies - EE);

b) proměnné, které ovlivñují autonomii učících se (autonomy support - AS);

c) vnější zaměření pozornosti na zamýšlený pohybový efekt (external focus - EF).

Teorie OPTIMAL vychází z vnitřní (autonomní) motivace učícího se, která především prostřednictvím zvýšeného (pozitivního) očekávání a zaměřením jeho pozornosti na vnější, cílový efekt nacvičované dovednosti vede $\mathrm{k}$ značné efektivitě jejího provedení a úspěšnému učení.

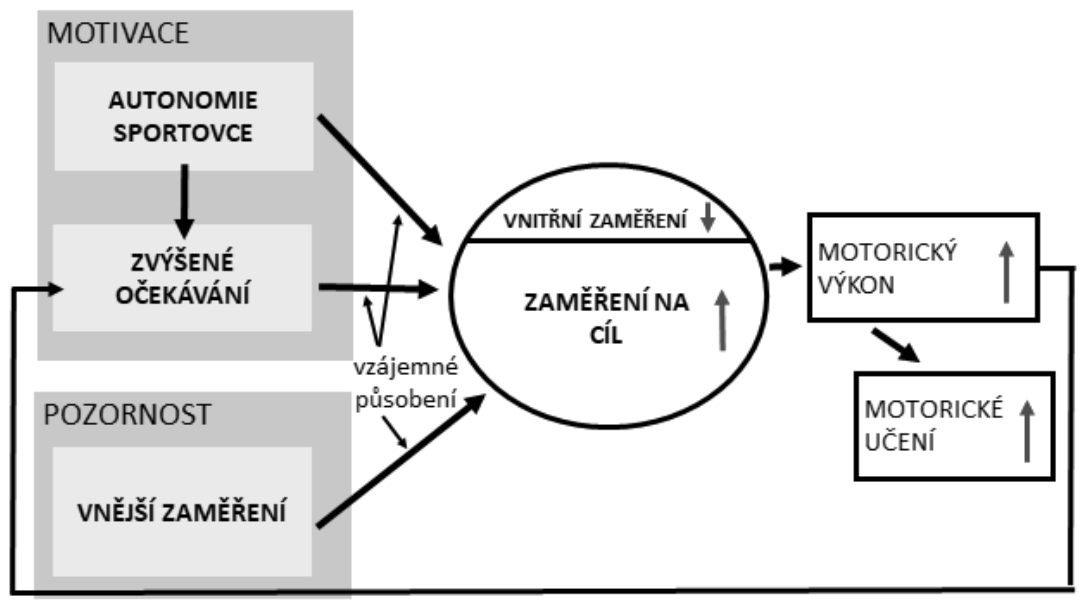

Schéma teorie OPTIMAL, volně dle Wulf \& Lewthwaite (2016)

Autorky tvrdí, že teorie OPTIMAL jde proti „tradičnímu“ př́stupu, kdy trenér či učitel zpravidla při nácviku nové dovednosti stanoví úkoly, popíše, jak by se měly pohyby provádět, poskytne korektivní zpětnou vazbu a instrukce týkající se koordinace pohybů těla. Při tomto přístupu je žákům vnucováno vnitřní zaměření pozornosti, tedy soustředěnost na pohyby těla či jeho částí. Instruktoři často opomíjejí své svěřence motivovat a navyšovat jejich očekávání, neuznávají a nepodporují jejich potřebu autonomie a vnucují jim zmíněné vnitřní zaměření pozornosti. Přimými důsledky takového přístupu jsou nízká vnímaná osobní účinnost (self efficacy) žáka, malý nebo žádný pozitivní výsledný efekt, zvýšené soustředění na sebe a omezená schopnost soustředit se na cíl úkolu. Nepřimé důsledky vyplývající ze špatného či malého zlepšení ve výkonu mohou vést $\mathrm{k}$ ještě většímu poklesu vnímání osobní účinnosti a prožitku pozitivních emocí, většímu zaměření na sebe, atd. - což může končit v bludném kruhu nepř́iliš úspěšného, „neoptimálního“ učení a ztrátě zájmu o danou činnost (Wulf \& Lewthwaite, 2016).

Praktickou ukázkou, na níž lze odlišnost nově navrhovaného př́istupu demonstrovat, může být golf. Golf je jedním ze sportů, kde se již tato nová teorie začala prakticky testovat. „Tradiční“ golfový př́stup spočívá $v$ interním zaměření pozornosti na pohyb těla a instrukce odkazují na pohyb trupu, paží a zápěstí. V př́stupu podle teorie OPTIMAL je instruktorem používáno externí zaměření pozornosti, a to na dráhu pohybu hlavy hole a zamíření úderové plochy v okamžiku impaktu (okamžik kontaktu s míčkem) nebo na zamýšlenou vzletovou dráhu míče. Tradiční instrukce pro provedení golfového švihu tak může znít: „Rotuj (otáčej) rameny kolem osy páteře a pažemi následuj pohyb trupu“, instrukce dle OPTIMAL: „Přived’ úderovou plochu hlavy hole kolmo na zamýšlený počáteční směr letu míče“.

Ve výše citovaném článku (Wulf \& Lewthwaite, 2016) je uvedena řada dílčích výzkumů, které jsou zmiňovanými „základními kameny“ teorie. S ohledem na jeden z cílů, jež jsme si v tomto př́ispěvku stanovili, tj. představit odborné veřejnosti hlavní myšlenky této teorie, si dovolujeme 
vzhledem $\mathrm{k}$ charakteru a rozsahu tohoto příspěvku omezit důslednou citaci všech podpůrných výzkumů a doufáme, že výběrem pouze některých z nich nezpůsobíme nemístné zkreslení. Věříme, že čtenář promine a $\mathrm{v}$ případě hlubšího zájmu, který jak doufáme, $\mathrm{v}$ něm probudíme, najde zbývající v primárním zdroji.

Mezi „základní kameny“ teorie OPTIMAL patři výzkumy, které podporují efektivitu vnějšího zaměření pozornosti (EF). Jejich výsledky hovoří o zlepšení koordinace ve svalech (tj. zapojení motorických jednotek) a mezi svaly, ale rovněž usnadnění koordinace ve větším měřítku. Podle provedených analýz kinematiky pohybu je zároveň prostř̌ednictvím vnějšího zaměření pozornosti možné optimalizovat formu provedení pohybu. Jedním ze sportů, kde byla testována úspěšnost vnějšího zaměření pozornosti, je veslování (Parr \& Button, 2009). Ukázalo se, že pokyny dávané veslařům-nováčkům zaměřené $\mathrm{k}$ upření jejich pozornosti na list vesla (např. „Udržujte list ve stejné rovině při pohybu zpět.“), vedly k velkému zlepšení v technice oproti pokynům směřujícím jejich pozornost na ruce (např. „Udržujte ruce ve stejné rovině při pohybu zpět.“).

V oblasti lidské motivace vyzdvihují Wulf a Lewthwaite (2016) význam autonomie i očekávané budoucnosti. Jednáme, když věříme, že máme v budoucnu vyhlídky na úspěch. Proto lze dle autorek soudit, že usnadníme motorické učení, budou-li v jeho průběhu navozeny takové podmínky, které zvyšují očekávaný výkon učícího se a reflektují jeho potřebu autonomie. V odůvodnění teorie OPTIMAL je uváděno množství výzkumných studií podporujících oprávněnost kladení důrazu na podporu zvyšování očekávání (EE) a je popisován pravděpodobný mechanismus zakořeněný v odezvách dopaminu na očekávání pozitivních zkušeností dočasně spojených s dovedností. Z hlediska podpory potřeby autonomie studenta (AS) se ukázalo, že aktivnější zapojení žáka do učebního procesu podporuje jeho hlubší zpracování relevantních informací (Chen \& Singer; as cited in Wulf \& Lewthwaite, 2016); odhad chyby (Chiviacowsky \& Wulf; as cited in Wulf \& Lewthwaite, 2016); použivání samoregulačních strategií (Kirschenbaum; as cited in Wulf \& Lewthwaite, 2016); vyšší zájem o práci (Lewthwaite et al., 2015) a větší motivaci k učení (Chiviacowsky, Wulf, Lewthwaite, \& Campos, 2012).

Autorky teorie uvádějí, že jsou si dobře vědomy potřeby dalších výzkumů a potřebné diskuse o praktických důsledcích teorie OPTIMAL.

\section{VYUŽITELNOST OPTIMAL V ŠKOLNÍ TĚLESNÉ VÝCHOVĚ A SPORTOVNÍCH HRÁCH}

Jak bylo naznačeno, teorii OPTIMAL je třeba z hlediska praktické aplikace dále testovat. I když její přenos do praxe v některých sportech jako například v uvedeném golfu (Wulf, Orr \& Chauvel, 2017) už probíhá a má, jak se zdá, úspěch, v oblasti školní tělesné výchovy a výuky dovedností ve sportovních hrách je zatím v úplných začátcích.

Nově navržená teorie motorického učení bere v úvahu společensko-kognitivně-emocionální povahu „motorického“ chování (Lewthwaite \& Wulf, 2010). Tato teorie nemá dle autorek řešit oblast dovedností, které mají silnou kognitivní nebo rozhodovací složku (tj. učení „co“). Soustředí se spíše na to „jak“ kvalifikovaně provést kontrolovaný koordinačně obtížný komplexní (složitý) pohyb, pro nějž má primární důležitost kvalita provedení.

Protože ve školní tělesné výchově klademe důraz na proces učení se pohybových dovedností jako na prostředek získávání správných motorických programů využitelných v budoucím životě našich žáků, jeví se praktické využití teorie OPTIMAL ve školní tělesné výchově jako vhodné. Je třeba poznamenat, že OPTIMAL je v souladu s aktuálním trendem podpory autonomie žáků. Ve školní tělesné výchově se v současnosti využívají některé z didaktických stylů, které jsou „za kognitivním prahem“. Mezi tyto didaktické styly (teaching styles), které lze ve školním prostředí použit, patří styl s řízeným objevováním, případně (s omezenějšími možnostmi) i styl se 
samostatným objevováním (Moosston \& Asworth, 2005). Přes bezesporná pozitiva spočívající ve vyšší motivaci žáků, přínosnější interakci mezi pedagogem a žákem (i mezi žáky samotnými) a efektivnějším učení, které podpora autonomie žáka nese, narážíme ve školní tělesné výchově na obtíže spojené s praktickými podmínkami. Mezi ně může patřit například vyšší počet žáků ve třídě a žáci s problémovým chováním. OPTIMAL kromě těchto omezení spojených s vyšší podporou autonomie žáků klade zároveň vysoké nároky na práci pedagoga. Zejména způsob, kterým jsou vydávány pokyny a poskytována zpětná vazba, vyžaduje značné zkušenosti nebo alespoň důkladnou prípravu.

Ve sportovních hrách se vyskytují (vzhledem k zmíněné proměnlivosti podmínek) především tzv. „otevřené“ dovednosti obsahující výraznou kognitivní a rozhodovací složku. Lze však předpokládat, že zvládnutí „dovedného provedeni“ pohybu, přesněji kvalitní zvládnutí technických dovedností při výuce základů herních činností jednotlivce, by později umožnilo jejich efektivnější integraci se strategickými a interaktivními rozhodnutími. Tuto domněnku nepřímo potvrzují studie (Kal, Van der Kamp \& Houdijk, 2013; Wulf, McNevin \& Shea, 2011), ze kterých vyplývá, že vnější zaměření pozornosti podporuje automatičnost pohybů. Zároveň se zdá, že vnější zaměření pozornosti na účinek zamýšleného pohybu rovněž zvyšuje „funkční variabilitu“ (Loosch, 1995).

Jak by vypadala například v basketbalu „tradični“ instrukce odkazující na postavení a pohyby těla a jeho segmentů? Např. při střelbě trestného hodu: „Soustřed’ se na postavení nohou na šiři ramen, s nohou střílející paže mírně vpřed.“ „Míč drž nad hlavou na dlani střílející paže a přidržuj ho druhou rukou.“ „Tvůj pohyb musí vycházet z pokrčených dolních končetin a plynule pokračovat propnutím paže v lokti a odhozením míče."

V teorii OPTIMAL instrukce zaměřující se vně (na cílový efekt) by mohly při stejné činnosti znít takto: „Zvol takové postavení, aby ses cítil dostatečně stabilní a připravený ke střelbě.“ „Než vystř̌elíš, zacil (zamiř), tj. podívej se pod míčem ,okénkem“ na koš.“ „Snaž se střílet vysokým obloukem, který směřuje na kruh koše."

V nácviku konkrétní dovednosti libovolné sportovní hry by mohl stručný scénář dle OPTIMAL vypadat takto: Instruktor dává hráči volbu, na žádost hráče poskytuje zpětnou vazbu, zdůrazñuje dobré aspekty výkonu (přičemž většinou ignoruje chyby), vyhýbá se odkazům na pohyby těla, a místo toho směřuje pozornost hráče vně $\mathrm{k}$ cíli úkolu. $\mathrm{V}$ takovémto případě by zvýšené očekávaní výkonu a vnímání autonomie pravděpodobně zvýšily self efficacy hráčů. Taková praxe při učení se dovednostem (posilování autonomie a zvýšení self efficacy hráčủ) by mohla nést ovoce i později při herních činnostech. Zejména $\mathrm{v}$ př́ípadě jevu ve sportovních hrách známého, kdy hráč již velmi dobře zvládá techniku herních dovedností, ale není schopen ji použít při hře samotné. Na vině mohou být právě psychologické faktory.

$\mathrm{S}$ podobnými př́stupy nebo alespoň některými principy, jaké jsou navrhovány $\mathrm{v}$ teorii OPTIMAL, se setkáváme řadu let. Například tzv. taktický model patří mezi nelineární př́stupy, které se objevují v nedávné i současné didaktice a praxi vyučování sportovních her na školách (Psotta \& Velenský, 2001). TGFU (Teaching Games for Understanding); (Bunker \& Thorpe, 1982; Werner, Thorpe \& Bunker, 1996 aj.) je již zakořeněno jako jedno z platných „didaktických“ paradigmat. „Základní myšlenkou jeho autorů je, že pochopení dané pohybové (sportovní) hry a rozvoj taktického vědění by měly předcházet zdokonalování pohybové stránky herních činností jednotlivce.“ (Dobrý, 2003) V TGFU je obdobně jako v OPTIMAL kladen důraz zaměření na cíl úkolu, kterým je ovšem v tomto případě praktická dovednost hrát konkrétní sportovní hru. Mezi potenciální výsledky tohoto „taktického paradigmatu“ patří „Zvýšený pocit zábavy, zájmu, výkonnosti“. To do jisté míry odpovídá principu vnitřní motivace podle OPTIMAL. Žáci, kteří již poznali hodnotu dobrého přihrávání a ovládání míče, mají kladný postoj k jejich nácviku. TGFU je př́stup orientovaný herně a výrazně na žáka. Učitel zde působí pouze jako facilitátor. Zde se projevuje značná podpora autonomie žáka dle teorie OPTIMAL tolik žádoucí. 


\section{ZÁVĚR}

Nová teorie motorického učení OPTIMAL autorek Wulf a Lewthwaite popisuje učební výhody proměnných (EE, AS, EF) opírající se o psychologické a neurovědní základy. Wulf a Lewthwaite uvádí, že v „tradični““ výuce novým pohybovým dovednostem je často opomíjena vnitřní motivace žáků a podpora jejich autonomie. Žákům je vnucováno vnitřní zaměření pozornosti, tedy soustředěnost na pohyby těla či jeho částí. Uvádí, že důsledkem takového přístupu je učení, které není dostatečně efektivní. Zvýšené soustředění na sebe a omezená schopnost soustředit se na cíl úkolu spolu se špatným výkonem nebo jen jeho velmi malým zlepšením mohou vést ke stále se snižující self efficacy žáka. Zdá se, že praktické využití teorie OPTIMAL ve školní tělesné výchově je možné. Zejména podporou autonomie sleduje aktuální trendy. Očekáváme však vysoké nároky kladené na organizaci učebního procesu i na pedagogy samotné. Je třeba budoucí testování ve školní praxi. Ve sportovních hrách je již řadu let úspěšně užíváno didaktické paradigma TGFU. Vzhledem k podobnosti některých principů teorie OPTIMAL a tohoto paradigmatu se jeví, že by i nová teorie motorického učení mohla být zejména při výuce základů herních dovedností ve sportovních hrách úspěšná. I to by však mělo být v budoucnu předmětem testování.

\section{Reference}

Bunker, D. \& Thorpe, R. (1982). A model for the teaching of games in secondary schools. In Bulletin of Physical Education, vol. 18 , no. 1, p. 5-8.

Dobrý, L. (2003). Přehledná studie o vývoji a současném stavu zkoumání herního výkonu a jeho osvojování. In Pedagogická kinantropologie. Praha: Karolinum, s. 36-87. ISBN 80-246-0767-0.

Chiviacowsky, S., Wulf, G., Lewthwaite, R., \& Campos, T. (2012). Motor learning benefits of self-controlled practice in persons with Parkinson's disease. Gait \& Posture, 35, 601-605.

Griffin, L. L. \& Butler, J. I. (2005). Teaching Games for Understanding. Champaign: Human Kinetics, ISBN 13: 9780736045940.

Kal, E. C., Van der Kamp, J., \& Houdijk, H. (2013). External attentional focus enhances movement automatization: A comprehensive test of the constrained action hypothesis. Human Movement Science, 32, 527-539.

Lewthwaite, R., \& Wulf, G. (2010). Grand challenge for movement science and sport psychology: Embracing the social-cognitiveaffective-motor nature of motor behavior. Frontiers in Psychology, 1(Article 42), 1-3. doi:10.3389/fpsyg.2010.00042

Lewthwaite, R., Chiviacowsky, S., Drews, R., \&Wulf, G. (2015). Choose to move: The motivational impact of autonomy support on motor learning. Psychonomic Bulletin \& Review, 22, 1383-1388.

Loosch, E. (1995). Funktionelle Variabilität in Dartwurf (Functional variability in dart throwing). Sportwissenschaft, 25, 417-425.

Mosston, M., \& Ashworth, S. (2002). Teaching physical education. (5th Ed). New York: Benjamin Cummings.

Parr, R., \& Button, C. (2009). End-point focus of attention: Learning the "catch" in rowing. International Journal of Sport Psychology, 40, 616-635.

Psotta, R. \& Velenský, M. (2001). Alternativní pojetí vyučování sportovních her ve školní tělesné výchově. In Pedagogická kinantropologie. Praha: Karolinum, s. 17-27. ISBN 80-246-0322-5.

Werner, P., Thorpe, R., \& Bunker, D. (1996). Teaching games for understanding: evolution of a model. The Journal of Physical Education, Recreation \& Dance, 67(1), 28-33.

Wulf, G., McNevin, N. H., \& Shea, C. H. (2001). The automaticity of complex motor skill learning as a function of attentional focus. Quarterly Journal of Experimental Psychology, 54A, 1143-1154. [NON VIDI]

Wulf, G. \& Lewthwaite, R. (2016). Optimizing performance trough intrinsic motivation and attenion for learning: The OPTIMAL theory of motor learning. Psychonomic Bulletin \& Review, vol. 23, no. 5, p. 1382-1414.

Wulf, G., Orr, S., \& Chauvel, G. (2017). Optimizing golf skill learning. In M. Toms (Ed.), The Routledge International Handbook of Golf Science, p. 88-97. London: Routledge.

\section{Korespondující autor:}

PhDr. Radka Peřinová, Ph.D.

perinova@ftvs.cuni.cz

tel. 725753782 